\section{THE SYMBOLIZATION OF SOUNDS IN THAI ONOMATOPOEIC WORDS ${ }^{1}$}

\section{Sorabud Rungrojsuwan ${ }^{2}$}

\begin{abstract}
In addition to the arbitrary invention of words in human language, there are also a number of lexical items in languages generated from the symbolization of particular groups of sounds. The present study investigates the structural and semantic characteristics of "soundsymbolic words" (or onomatopoeic words) in Thai. Data were drawn from formal and informal written documents. The Royal Institute's and Matichon's dictionaries were used as representatives of formal documents, while 40 Japanese-to-Thai translated comics were used for the informal documents. Structurally, it was found that most sound-symbolic words are either monomorphemic or reduplicated. In relation to semantics, sound symbolization in the data shows semantic relations to human behaviors, activities, and surroundings.
\end{abstract}

\footnotetext{
${ }^{1}$ This article is a part of a research project entitled "Sound-symbolic words in Thai" funded by Thailand Research Fund 2005-2007. I would like to express my deep appreciation to Professor Emeritus Dr. Pranee Kullavanijaya, the mentor for the present project, for her insightful comments and encouragement. Without her help, this article would never have been possible.

${ }^{2}$ Lecturer, School of Liberal Arts, Mae Fah Luang University, Chiang Rai, Thailand.
}

\section{Research background}

\author{
The symbolization of sounds
}

Language is a symbolic system that conveys ideas, attitudes, and emotions to other people with patterns of sounds or writing. Normally, the relationship between the meaning and the form of a word is said to be "arbitrary." This means that there is no reasonable explanation why a word is used to refer to a particular entity. Take the word $\langle\text { cat }\rangle^{3}$ for example. The letters $\langle\mathrm{c}\rangle,\langle\mathrm{a}\rangle$, and $\langle\mathrm{t}\rangle$, or the sounds $/ \mathrm{kh}^{4} /^{5}$, / $/ \varepsilon /$, and $/ \mathrm{t} /$ do not show any relationship or do not even give any clue to the referent $[\mathrm{CAT}]^{6}$ at all. In other words, the symbolization process of words is said to be "arbitrary."

However, some words in human language are not arbitrarily symbolized. This group of words is known as "onomatopoeic words." While other groups of words in language are the products of the symbolization of physical and abstract entities, onomatopoeia are the products of the symbolization of actual sounds. Simply speaking, onomatopoeic words imitate sounds using language-specific-based phonetic and phonological systems. Normally, the phonetic characteristics of "onomatopoeia" are similar to the particular sound referent of a particular word. The word $<$ meow $>$, for example, is used to refer to the sound of a cat or cat's

\footnotetext{
${ }^{3}$ The symbol $<$ aaa $>$ is used to show the written form of a word.

${ }^{4}$ Thai phonological system is described in Appendix A.

${ }^{5}$ The symbol /aaa/ is used to show the phonetic characteristic of a word.

${ }^{6}$ The symbol [AAA] is used to show the meaning of a word.
} 
[MEOW]. This indicates the direct relationship between a linguistic form (word) and a particular meaning (actual sound). Words with such relationships will be referred to as "sound-symbolic words" in this paper.

\section{Universality of sound-symbolic words}

Compared to the arbitrarily invented words in a language, sound-symbolic words are obviously fewer in number. Because of this, most linguists see no need to investigate this group of words in depth. However, considering sound-symbolic words across languages, it has been found that there seems to be some similarities in the use of phonetic representations across languages, as shown in the following examples of the items referring to [CHICKEN'S SOUND].
It should be noted that the study of soundsymbolic words in languages has been of less interest for most researchers because the proportion of this group of words in languages is extremely small (Hinton et al. 1994). In Thai, although the study of "sound symbolism" has focused its attention mainly to "reduplicatives" (Udomanisuwat 1982, Liamprawat 1983, Suttasorn 1987), the classification and explanation about "onomatopoeic words" have never been explicitly proposed. Therefore, this group of words has attracted little or no attention from Thai researchers, so it is still unknown how sound-symbolic words are formed and what kinds of meaning these words refer to. The present study is a preliminary attempt to indicate areas for the further indepth studies of sound-symbolic words from the universal and language specific points of view.

$\begin{array}{lc}\begin{array}{l}\text { Language } \\ \text { English }\end{array} & \text { Orthographic Representation } \\ \text { Thai } & <\text { cocka-doodle-doo }> \\ & <\text { กุ๊กๆ }> \\ & <\text { เอกอี๊เอ้กเอ้ก }> \\ \text { Japanese } & <\text { kokekokkoo }>\end{array}$

It can be seen that when referring to a chicken's sound, many of the world's languages - such as English, Thai, and Japanese-employ similar phonetic representations-i.e. $/ \mathrm{k} /$, open syllables - and similar morphological characteristics - i.e. polysyllabic monomorphemic words and reduplication. Such evidence seems to imply the universality of human "symbolization processes" of soundsymbolic words. In other words, a particular referent is signified by similar linguistic symbols across languages.
Phonetic Representation

/k ${ }^{\mathrm{h}}$ okadu:dəldu:/

/kúk kúk/,

/Rèk Piii Pêek Pêek/

/kokekoko:/

\section{Objectives of this study}

This study aims to investigate the structural and semantic characteristics of sound-symbolic words in selected Thai formal and informal written documents. 


\section{Hypothesis}

The structural and semantic characteristics of sound-symbolic words in Thai formal and informal printed documents are similar.

\section{Data}

\section{Source of data}

Data in this study were collected from two Thai monolingual dictionaries - which were used as representatives of formal printed documents - and 40 comic books drawn 10 each from four different titleswhich were used as representatives of informal printed documents as follows.

\section{Formal printed documents}

Two Thai dictionaries-The Royal Institute's 1999 Dictionary and Matichon Dictionary of Thai Language-were used for the collection of sound-symbolic words from formal printed documents. The Royal Institute's Dictionary is widely accepted as the standard dictionary of the Thai language, while Matichon Dictionary of Thai Language is the most up-to-date dictionary of everyday language use. These two dictionaries were selected to represent formal Thai sound-symbolic words. The selection of sound-symbolic words in formal dictionaries is based on the following working criteria.

1) The selected words are classified as adverbs.

2) The words are defined as 'sound of...'.

3) Words used in poetry or old words will not be included.

\section{Informal printed documents}

Data for informal printed documents were drawn from 40 Japanese-to-Thai translated comic books in four different titles-10 items for each. The four titles are those on four different themes-The Sushi Boy (food), D.D.S. Dan Detective School (detective), Rave: The Groove Adventure (action), and Kaikan-Phrase (love stories).

The comic books obviously contain higher numbers of sound-symbolic words than other printed documents. Although the original versions are in Japanese, the Japanese-to-Thai translators normally adopt Japanese to Thai sounds. Japaneseto-Thai translated comic books have become extremely popular in Thai society. Because of this, compared to Thai comic books, Japanese-to-Thai comic books are widely read and might influence the formation and usage of sound-symbolic words in Thai. Therefore, these comic books were selected as representatives of informal printed documents.

Although language in comic books is written, it is conversational and informal. There are no definitions of words given in the documents, but drawn figures help to interpret meanings of the target words. Therefore, the selection criteria of soundsymbolic words in this type of document mainly depended on the researcher's interpretations and the following guiding ideas.

1) The selected words are those that represent sounds.

2) The same word forms which occur in the same context will be selected only once as in the examples. 


\section{Form Meaning \\ /màp/ [TO CATCH SOMETHING] \\ /màp màp/ [TO CATCH SOMETHING] \\ /màp/ [TO CATCH SOMETHING]}

From the above three examples, only two, /màp/ and /màp màp/ were selected.

\section{Analyses}

The analyses of sound-symbolic words in this study were divided into two major parts, structural analysis and semantic analysis.

\section{Structural analysis}

The forms of sound-symbolic words from both types of documents will be classified according to the following criteria.

(1) Spelling accuracy according to Thai syllable structures

(2) Number of syllables

(3) Word formation

(4) Substitution of forms for a particular sound meaning

Thereafter, findings from two sources of documents will be compared.

\section{Semantic analysis}

In terms of meaning, the semantic domains of sound-symbolic words will be analyzed into five semantic domains:

(1) [HUMAN]

(2) [ANIMAL]

(3) [THING]

(4) [NATURAL PHENOMENA]

(5) $[\mathrm{CUE}]$

\section{Results}

\section{Structural characteristics of sound- symbolic words in Thai}

\section{Spelling accuracy}

In relation to "spelling accuracy," soundsymbolic words which have accurate spelling are words which follow spelling rules in Thai language. It was found that all sound-symbolic words in the formal printed documents (dictionaries) have accurate spelling. On the other hand, informal printed documents (translated comic books) have both correct and incorrect styles of sound-symbolic words as shown in Figure 1.

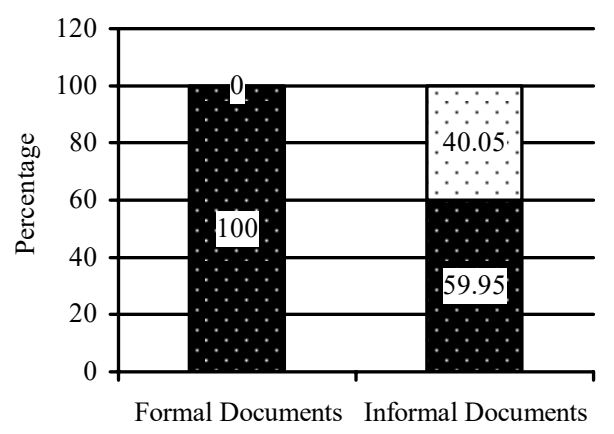

Accurate spelling $\square$ Inaccurate spelling

Figure 1: Proportions of spelling accuracy of sound-symbolic words in formal and informal documents

From Figure 1, it can be seen that about three-fifths of sound-symbolic words in the informal printed documents are accurately spelled, and all items in the formal printed documents are spelled correctly. This shows the degree of formality of the two types of documents. 
Considered in more detail, Table 1 demonstrates some examples of soundsymbolic words found in the data based on their spelling accuracy.

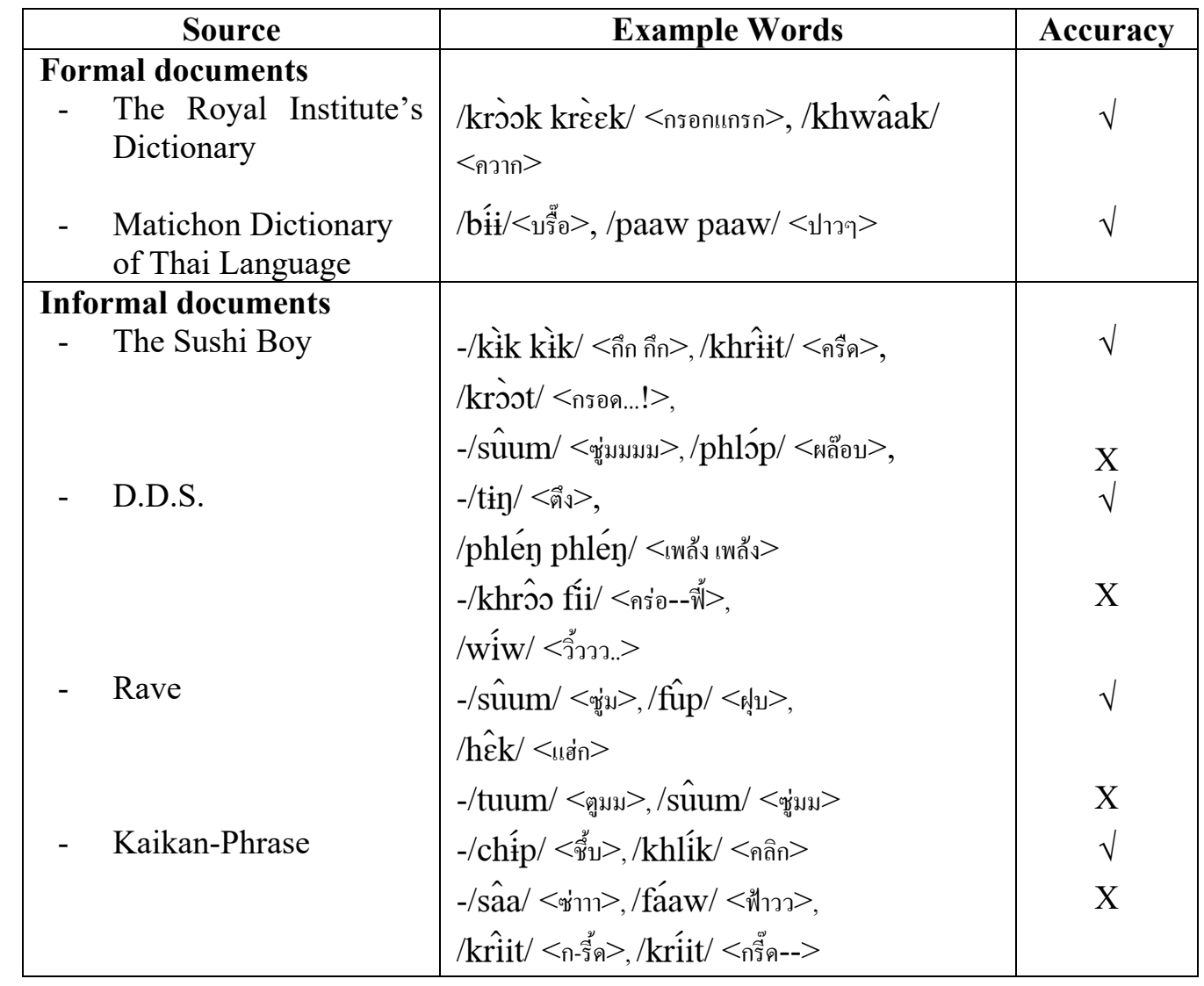

Table 1: Accuracy in spelling of sound-symbolic words in formal and informal documents

Data in the informal printed documents contain two types of inaccurate spelling. The first type is the misspelling of words using letters in the language as shown in the following examples.

\begin{tabular}{|c|c|c|}
\hline Phonetic & $\begin{array}{l}\text { Inaccurate } \\
\text { spelling }\end{array}$ & $\begin{array}{c}\text { Accurate } \\
\text { spelling }\end{array}$ \\
\hline /sûum/ & <ซู่มมมม > & $<$ ซู่ม $>$ \\
\hline /phló & $<$ ผล๊อบ> & <พล็อบ> \\
\hline /kríit/ & $<$ กรี้ด $>$ & $<$ กรี๊ด $>$ \\
\hline
\end{tabular}

The second type of inaccurate spelling includes that with other non-alphabetic symbols - such as -, !, and ?-for making sound-symbolic words as shown in the examples.

\begin{tabular}{|c|c|c|}
\hline Phonetic & $\begin{array}{l}\text { Inaccurate } \\
\text { spelling }\end{array}$ & $\begin{array}{l}\text { Accurate } \\
\text { spelling }\end{array}$ \\
\hline /kroot/ & $<$ กรรอด...!> & $<_{\text {กรอด }}>$ \\
\hline /krii & <กรี๊ด--> & <กรี๊ด> \\
\hline /Ré?/ & $<$ <อ๊ะ!? > & $<$ เอ๊๊ $>$ \\
\hline
\end{tabular}


It is possible that the misspelling of words in the comics is due to the specific characteristics of this type of document. To attract its readers' attention, a comic book might have to include well-drawn and clear pictures, colorful paintings on some pages, clearly and emotionally attractive letters arranged in different sizes and with deviant spellings. These stylistic factors required attention for the investigation in the part of informal printed documents.

\section{Number of syllables}

In relation to the number of syllables of sound-symbolic words in this study, Table 2 demonstrates examples of items with different number of syllables.

\begin{tabular}{|c|c|c|}
\hline $\begin{array}{l}\text { Number of } \\
\text { syllables }\end{array}$ & Formal documents & Informal documents \\
\hline 1 & 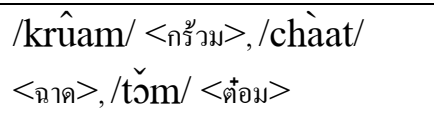 & 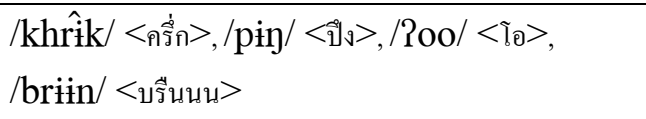 \\
\hline 2 & $\begin{array}{l}\text { /ka táak/ <กะต๊าก>, /kin } \\
\text { kay/<กึงกัง>,/hôyhôy/ } \\
<\text { โฮ่งๆ> }\end{array}$ & 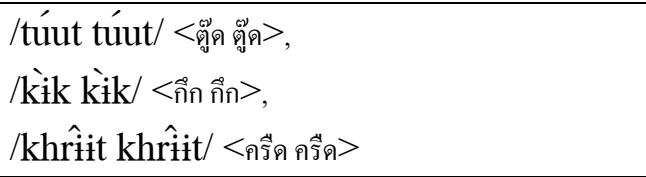 \\
\hline 3 & $\begin{array}{l}\text { /ka tôon hoon/ } \\
\text { <กะโต้งโห่ง>, } \\
\text { /huj lee huj/ <สุยเลฮุย> }\end{array}$ & 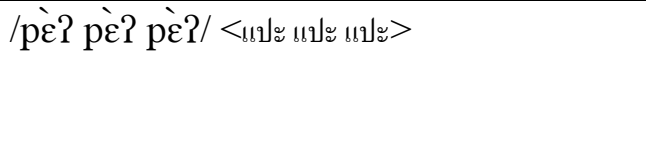 \\
\hline 4 & $\begin{array}{l}\text { /ka nǔn ka nīy/ } \\
<\text { กะหนุงกะหนิง }>\end{array}$ & $\begin{array}{l}\text { /pík pík pík pík/ } \\
<\text { <ปึ๊ก ปึ๊ก ปึ๊ก ปึ๊ก> }\end{array}$ \\
\hline 5 & $\begin{array}{l}\text { /wiit wáaj ka tûu wúu/ <วี้ด } \\
\text { ว้ายกะตู้ว }>\end{array}$ & $\begin{array}{l}\text { /hee hee hee hee hee/ } \\
<\text { เฮ เฮ เฮ เฮ เฮ }\end{array}$ \\
\hline 6 & $\begin{array}{l}\text { /hee la loo sǎa la phaa/ } \\
\text { <เฮละโลสาระพา> }\end{array}$ & $\begin{array}{l}\text { /mâp mâp mâp mâp mâp mâp/ <มั่บ มั่บ มั่บ } \\
\text { มั่บ มั่บ มั่บ> }\end{array}$ \\
\hline 7 & - & $\begin{array}{l}\text { /hee hee hee hee hee hee hee/ <เฮ เฮ เฮ เฮ เฮ } \\
\text { เฮเ > }\end{array}$ \\
\hline 8 & - & 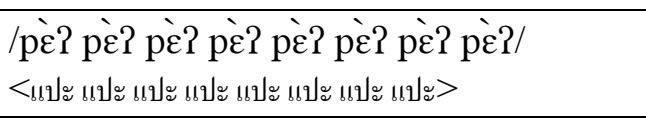 \\
\hline 9 & - & 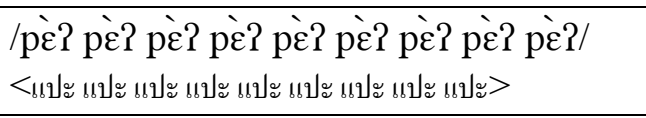 \\
\hline 11 & - & 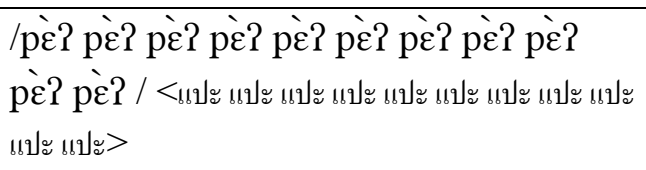 \\
\hline
\end{tabular}

Table 2: Number of syllables of sound-symbolic words in formal and informal documents 
Table 2 indicates that the number of syllables of sound-symbolic words in formal printed documents ranges from one to six syllables, while the informal printed documents contain from one to elevensyllable words. Moreover, it should be noted that most of polysyllabic soundsymbolic words (two to eleven-syllable words) in the informal printed documents derived from monosyllabic words. In other words, polysyllabic sound-symbolic words in translated comic books are mostly reduplicative. This might imply that reduplication plays an important role in the production of sound-symbolic expressions in informal printed documents (see more results in "Word Formation" section.) In addition, it might be possible that there are reduplicative soundsymbolic expressions which contain more than 11 syllables in this type of document.

In addition, Figure 2 demonstrates the proportions of sound-symbolic words in the two types of documents as shown.

Formal Documents

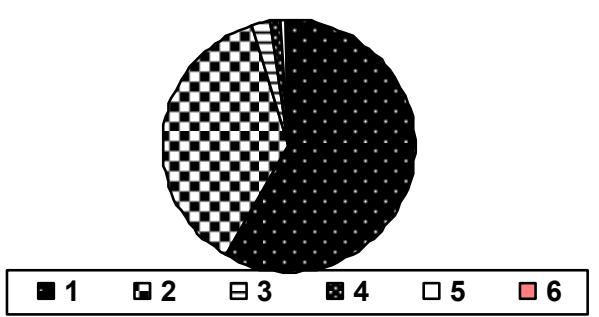

Figure 2 shows that the proportions of monosyllabic sound-symbolic words are quite similar in both types of documents. However, the informal printed documents seem to contain more items with different numbers of syllables than the formal printed documents.

\section{Word formation}

It is suggested that there are two types of words tied to the process of producing sound-symbolic words.

\section{Monomorphemic words}

The first type of word is called "Monomorphemic words." By "monomorphemic," it means that regardless of number of syllables, the particular soundsymbolic words have only one meaning and all units or syllables which are combined into one word cannot be separated. Examples of monomorphemic sound-symbolic words are:

\section{Informal Documents}

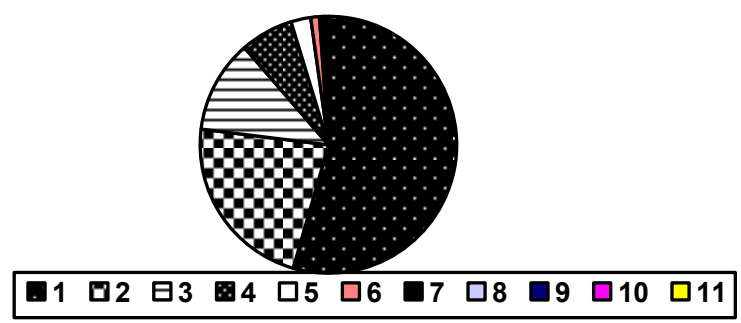

Figure 2: Proportions of sound-symbolic words with different numbers of syllables (1-11) found in formal and informal documents 


\begin{abstract}
Formal $\quad / \hat{\text { fup }} /<$ ฟุ่บ>
documents: $\quad$ /thôn boy/ <เทิ่งบอง>

Informal /phló?/ <โพพล๊ะ $>$,

documents: $\quad$ /khrôok fíi / < คร่อก--ฟี้-->

It should be noted that most monomorphemic sound-symbolic words in the informal printed documents are monosyllabic, while they range from one to six syllables in the formal printed documents.
\end{abstract}

\section{Patterns of reduplication}

Reduplication found in the present study may be classified into two types: complete reduplication and partial reduplication.

\section{Complete reduplication}

"Complete reduplication" refers to more than one phonetically the same monomorphemic words which are combined together into one word. In other words, it is formed by the unlimited repetition of "Monomorphemic Words." Examples of complete reduplicative sound-symbolic words are:

$\begin{array}{ll}\text { Formal } & \text { /phàay phàay/<ผ่างๆ>, } \\ \text { documents: } & \begin{array}{l}\text { /kùk kùk kàk kàk/ } \\ <\text { กุกๆ กักๆ> }\end{array} \\ \text { Informal } & \begin{array}{l}\text { /khriin khriin/ } \\ \text { <ocuments: }\end{array} \\ & \begin{array}{l}\text { <รืนนน ครืนน> } \\ \text { phim pham / <พึ่มพำ พึมพำ> }\end{array}\end{array}$

Complete reduplication is found to be an important process in making polysyllabic words in informal printed documents. Complete-reduplicated sound-symbolic words found in the comic books range from two to eleven syllables.

\section{Partial reduplication}

"Partial reduplication" is the process of carrying over some sound/s or character/s of the first syllable into other syllables. It might repeat only the initial consonant/s (onset), the vowel (nucleus), or the all except the initial consonant/s (rhyme), etc. Such reduplication can also be seen as the assimilation of some sounds into the following syllable/s. Examples of partial reduplicative are found only in the formal printed documents (dictionaries).

\begin{tabular}{|c|c|}
\hline Formal & / krik kraaw/ < กริกกราว> \\
\hline documents: & 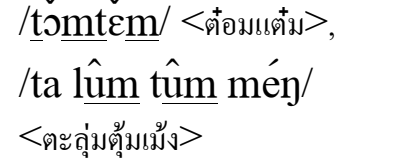 \\
\hline
\end{tabular}

Informal /phim pham/ $\quad$ พพึมพำ> documents:

Partial reduplication is more often used in formal printed documents and in informal printed documents.

Partial-reduplicated sound-symbolic words in the formal and informal printed documents range from one to six syllables, and from one to two syllables, respectively.

For the distribution of these two types of word forms in the data, it was found that reduplicatives are slightly more frequent in 
informal printed documents than in formal printed documents as shown in Figure 3.

From Figure 3, it can be seen that the formal printed documents employ reduplication as the word formation process for $38.4 \%$ of the data, while the informal printed documents contain $45.5 \%$ of reduplicated words. As mentioned in the earlier section about the number of syllables of words, polysyllabic words in the informal printed documents are mostly reduplicative. The proportions of word formation in this section also conform to the previous findings. words can be classified into the following five domains.

\section{[HUMAN]}

Sound-symbolic words in the [HUMAN] domain include words which refer to sounds occurring purely due to human body's actions, such as crying, laughing, punching, running, snoring, vomiting, etc., as shown in the following examples.

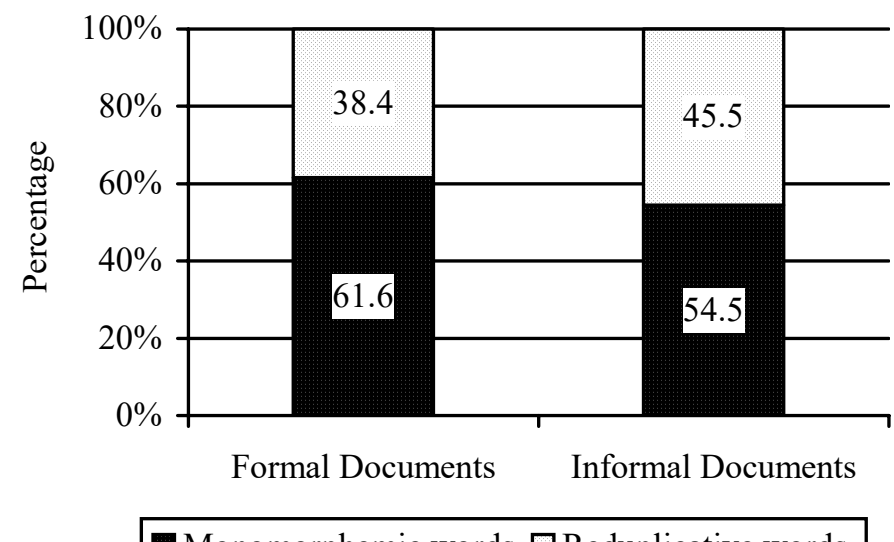

Figure 3: Proportions of monomorphemic and reduplicative sound-symbolic words in formal and informal documents

\section{Semantic characteristics of sound- symbolic words in Thai}

What kinds of sounds are usually symbolized? The meaning of soundsymbolic words in Thai data is basically related to human beings and their surroundings. Sound referents of the

$\begin{array}{ll}\begin{array}{l}\text { Sound-symbolic } \\ \text { words }\end{array} & \text { Meaning } \\ \text { /súut/ } & \text { [DRINKING WATER] } \\ \text { /krùap/ } & \text { [CHEWING] } \\ \text { /khik khik/ } & \text { [LAUGHING] } \\ \text { /khròok/ } & \text { [SNORING] } \\ / \text { hát chôj/ } & \text { [SNEEZING] } \\ / \text { Rûak/ } & \text { [VOMITING] }\end{array}$




\section{[ANIMAL]}

The [ANIMAL] domain includes words referring to sounds made by animals and their actions such as flying, barking, crying, etc., as shown in the following examples.

$\begin{array}{ll}\begin{array}{l}\text { Sound-symbolic } \\ \text { words } \\ \text { /préeprén/ }\end{array} & \text { Meaning } \\ & \text { [ELEPHANT } \\ \text { /h̀̀n h̀̀n/ } & \text { TRUMPETING] } \\ \text { /hôy/ } & \text { [BEE FLYING] } \\ & \text { [DOG } \\ & \text { BARKING] }\end{array}$

\section{[THING]}

Sound-symbolic words in the [THING] domain include words which refer to sounds of objects that might occur from the actions of human beings, such as taking photos, fighting with swords, shutting doors, etc., or occur without the actions of humans, such as the sound of boiling rice, alarm clock ringing, glass breaking, etc. Examples of words in this domain are shown below.

$\begin{array}{ll}\begin{array}{l}\text { Sound-symbolic } \\ \text { words }\end{array} & \text { Meaning } \\ \text { /ché?/ } & \text { [SNAPPING } \\ & \text { PHOTO] } \\ \text { /pan/ } & \text { [DOOR } \\ & \text { SHUTTING] } \\ \text { /brìn/ } & \text { [CAR MOTOR } \\ & \text { RUNNING] } \\ \text { /phléy/ } & \text { [GLASS } \\ & \text { BREAKING] }\end{array}$

[NATURAL PHENOMENA]

As the name refers, the [NATURAL PHENOMENA] domain includes words depicting sounds occurring in nature such as rain, thunder, wind blowing, earthquake, etc.

$\begin{array}{ll}\begin{array}{l}\text { Sound-symbolic } \\ \text { words }\end{array} & \text { Meaning } \\ / \mathrm{khriin} / & \text { [THUNDER] } \\ / \mathrm{priaj} / & \text { [LIGHTNING] } \\ / \text { sâa/ } & \text { [SOUND OF } \\ & \text { OCEAN WAVES] } \\ / \text { sâa/ } & \text { [RAINING] } \\ / \text { fáaw/ } & \text { [WIND } \\ & \text { BLOWING] } \\ \text { [CUE] } & \end{array}$

Sound-symbolic words in the [CUE] domain are found only in the informal printed documents. A comic book is a kind of drama production that uses pictures and orthographies as its media. According to this, it is still necessary to retain some characteristics of drama, especially music or melodies to show the moods of characters and scenes. From the author's interpretation of the pictorial contexts of the comic books, some words are used to refer to a new melody or sound which shows a specific cue in each scene. This group of sounds indicates the appearance of new characters in the particular scenes, cues for internal monologue of the particular characters, cues indicating some emotional states-such as surprise and fear-of particular characters. The following are examples of sound-symbolic words in the [CUE] domain.

$\begin{array}{ll}\begin{array}{l}\text { Sound-symbolic } \\ \text { words }\end{array} & \text { Meaning } \\ \text { /kik/ } & \\ \text { /tìk/ } & \text { [PENSIVE] } \\ \end{array}$




$\begin{array}{ll}\begin{array}{l}\text { Sound-symbolic } \\ \text { words } \\ \text { /pín/ }\end{array} & \text { Meaning } \\ & \text { [A NEW } \\ & \text { CHARACTER } \\ \text { /phàay/ } & \text { APPEARS] } \\ & \text { [A NEW } \\ & \text { CHARACTER } \\ & \text { APPEARS] }\end{array}$

The distribution of sound-symbolic words in these five semantic domains is seen in Figure 4.

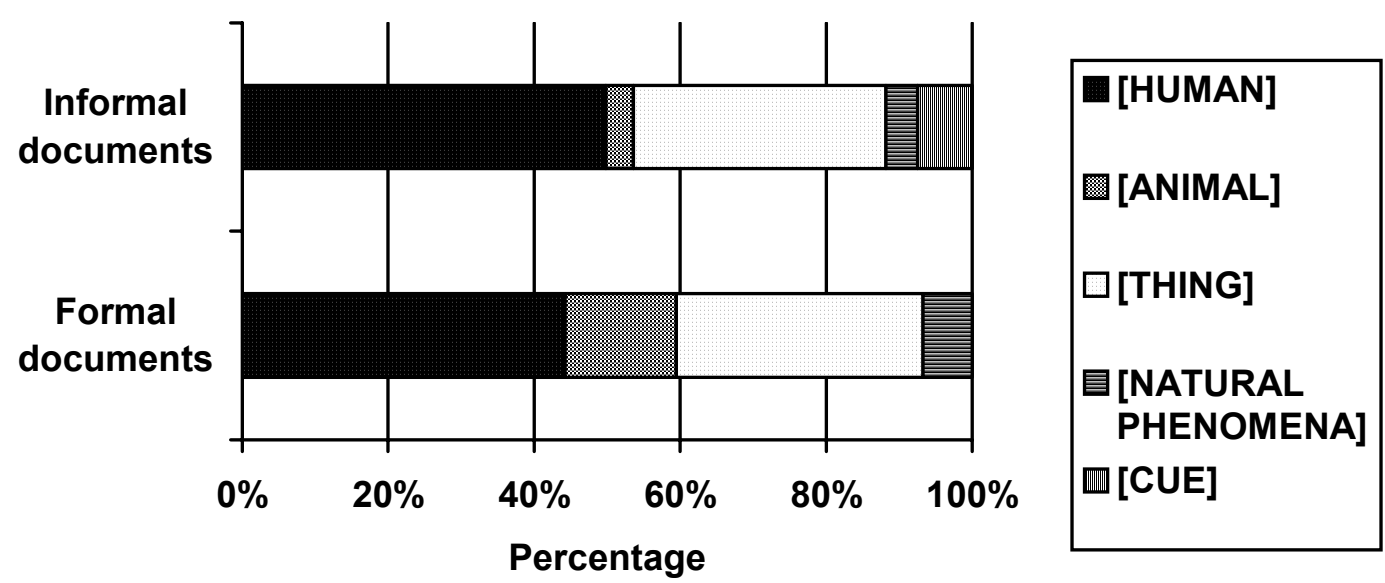

Figure 4: Proportions of sound-symbolic words in five semantic domains

From Figure 4, it was found that the proportions of sound-symbolic words in the five semantic domains range from the highest to the lowest as follows:

Formal printed documents: $[$ HUMAN] $>$ [THING] $>$ [ANIMAL $]>$ [NATURAL PHENOMENA]

Informal printed documents: $[$ HUMAN $]>[$ THING $]>[$ CUE $]>$ [NATURAL PHENOMENA] $>$ [ANIMAL]

It can be seen that more than eighty percent of sound-symbolic words in both formal and informal printed documents are in [HUMAN] and [THING] domains. This implies that sounds related to human beings and their behaviors-including their actions upon other actual objectsare mainly recognized and symbolized. The [CUE] domain is another significant domain found in informal printed documents. 
In relation to their semantics, it was found that actual sounds which have been selected and symbolized as soundsymbolic words are often those which relate to actions and internal states of humans and animals, surrounding things, and natural phenomena. In addition, another significant semantic domain found only in the informal printed documents is [CUE]. The [CUE] domain refers to the use of sound-symbolic words to indicate the appearance of new characters, and the internal states of the characters-such as surprise, thought, etc. The use of soundsymbolic words in the [CUE] domain is claimed to derive from the dramatic characteristics of comic books.

\section{References}

Hinton, L., Nichold, J., and Ohala, J. (eds). 1994. Sound Symbolism. Cambridge University Press.

Liamprawat, Suwatana. 1983. Reduplication of Lanna (Northern Thai Dialect). M.A. Thesis, Graduate School, Mahidol University. (In Thai).

Matichon Dictionary of the Thai Language. 2004. The Matichon Publishing Company.

Rungruangsri, Udom. 1990. Mae Fah Luang's Lanna-Thai Dictionary. Chiang Mai : Mingmuang.

Suttasorn, Wasana. 1987. Reduplication of Lao in Phuwiang Dialect. M.A. Thesis, Graduate School, Mahidol University. (In Thai).

The Royal Institute. 1999. The Royal Institute's Dictionary 1999.
Udomanisuwat, Apiradee.1982. Relations Of Vowels Patternings and Meanings of Disyllabic Reduplicatives in Thai. M.A. Thesis, Department of Linguistics, Graduate School, Chulalongkorn University. (In Thai). 


\section{Appendix A}

Thai Phonological System

\section{Segmentals}

\subsection{Consonants}

\begin{tabular}{|c|c|c|c|c|c|c|}
\hline \multicolumn{2}{|c|}{$\begin{array}{l}\text { Place of articulation } \\
\text { Manner of articulation }\end{array}$} & Labial & Alveolar & Palatal & Velar & Glottal \\
\hline \multirow{3}{*}{ Stop } & vl. unasp. & $\mathrm{p}$ & $\mathrm{t}$ & $\mathrm{c}$ & $\mathrm{k}$ & $?$ \\
\hline & vl. asp. & $\mathrm{ph}$ & th & $\mathrm{ch}$ & $\mathrm{kh}$ & \\
\hline & vd. & $\mathrm{b}$ & $\mathrm{d}$ & & & \\
\hline \multirow{5}{*}{ Non-stop } & Nasal & $\mathrm{m}$ & $\mathrm{n}$ & & $\eta$ & \\
\hline & Fricative & $\mathrm{f}$ & $\mathrm{S}$ & & & $\mathrm{h}$ \\
\hline & Trill & & $\mathrm{r}$ & & & \\
\hline & Lateral & & 1 & & & \\
\hline & Approximant & $\mathrm{W}$ & & $\mathrm{j}$ & & \\
\hline \multicolumn{2}{|c|}{ Consonant Clusters } & $\begin{array}{c}\text { pr, pl, } \\
\text { phr, phl }\end{array}$ & tr, thr & & $\begin{array}{l}\mathrm{kw}, \mathrm{kr}, \\
\mathrm{kl}, \mathrm{khw}, \\
\mathrm{khr}, \mathrm{khl}\end{array}$ & \\
\hline
\end{tabular}

\subsection{Vowels}

\begin{tabular}{|l|c|c|c|c|}
\hline Monophthongs & $\begin{array}{c}\text { Tongue Advancement } \\
\text { Tongue Height }\end{array}$ & Front & Central & Back \\
\cline { 2 - 5 } & High & i, ii & $\dot{\mathrm{i}}, \mathrm{ii}$ & $\mathrm{u}, \mathrm{uu}$ \\
\cline { 2 - 5 } & Mid & e, ee & , , əə & o, oo \\
\cline { 2 - 5 } & Low & $\varepsilon, \varepsilon \varepsilon$ & a, aa & , , ว \\
\hline Diphthongs & ia & ia & ua \\
\hline
\end{tabular}

\section{Suprasegmentals}

\section{Tones}

\begin{tabular}{|c|c|}
\hline Tone characteristics & Symbols \\
\hline Mid level & 33 \\
\hline Low falling & $21, \hat{0}$ \\
\hline High falling & $42, \hat{0}$ \\
\hline High rising & $45, \hat{0}$ \\
\hline Low rising & $24, \hat{0}$ \\
\hline
\end{tabular}

